\title{
Analisis kemampuan pemecahan masalah matematika pada materi pola bilangan ditinjau dari gaya kognitif reflektif-impulsif
}

\author{
Nurul Indah ${ }^{*}$, Sudi Prayitno², Amrullah², Baidowi ${ }^{2}$ \\ ${ }^{1}$ Mahasiswa Pendidikan Matematika, FKIP, Universitas Mataram, Mataram \\ ${ }^{2}$ Pendidikan Matematika, FKIP, Universitas Mataram, Mataram \\ indahnurul767@gmail.com \\ Diterima: 15 Juni 2021; Direvisi: 29 Juni 2021; Dipublikasi: 30 Juni 2021
}

\begin{abstract}
This study aimed to describe the mathematical problem solving ability of class VIII MTsN 1 Mataram at academic year 2019/2020 in solving numbers pattern problems based on reflective and impulsive cognitive styles. This type of research was quantitative descriptive research. The subjects in this study were students of class VIII-6 MTsN 1 Mataram at academic year 2019/2020. Data retrieval were done by using the cognitive test and the test results of problem solving. Based on the results of the study, it was found that the number of reflective students were 14 students $(63,6 \%)$ who were distributed into 5 students (22,7\%) with high ability, 7 students $(31,8 \%)$ with moderate ability, and 2 student $(9,1 \%)$ with low ability. While the number of impulsive students were 8 students who distributed into 5 students $(22,7 \%)$ with medium ability and 3 students $(13,6 \%)$ with low ability. Those results showed that there were differences in problem solving abilities between students who had reflective and impulsive cognitive styles. Reflective students in solving problems had been able to meet all the indicators at the problem solving stage according to Polya namely understanding the problem, thinking about the plan, carrying out the plan, and looking back. While impulsive students in solving problems had been able to fulfill the indicators thinking about plans and implementing plans. Impulsive students tend to skip the stages of understanding a problem and looking back.
\end{abstract}

Keywords: Cognitive Style; Number Patterns; Problem Solving; Reflective-Impulsive

\begin{abstract}
Abstrak
Penelitian ini bertujuan untuk mendeskripsikan kemampuan pemecahan masalah matematika siswa kelas VIII MTsN 1 Mataram tahun ajaran 2019/2020 dalam menyelesaikan soal pola bilangan berdasarkan gaya kognitif reflektif dan impulsif. Jenis penelitian yang digunakan adalah penelitian deskriptif kuantitatif. Subjek dalam penelitian ini adalah siswa kelas VIII-6 MTsN 1 Mataram tahun ajaran 2019/2020. Pengambilan data dilakukan dengan menggunakan instrumen tes gaya kognitif dan soal tes pemecahan masalah. Hasil penelitian didapatkan bahwa banyaknya siswa reflektif adalah 14 siswa $(63,6 \%)$ yang terdistribusi menjadi 5 siswa (22,7\%) berkemampuan tinggi, 7 siswa (31,8\%) berkemampuan sedang, dan 2 siswa $(9,1 \%)$ berkemampuan rendah. Sedangkan banyaknya siswa impulsif adalah 8 siswa (36,3\%) yang terdistribusi menjadi 5 siswa (22,7\%) berkemampuan sedang dan 3 siswa (13,6\%) berkemampuan rendah. Hal ini menunjukkan adanya perbedaan kemampuan pemecahan masalah antara siswa yang memiliki gaya kognitif reflektif dan impulsif. Siswa reflektif dalam menyelesaikan masalah telah dapat memenuhi semua indikator pada tahapan pemecahan masalah menurut Polya yaitu memahami masalah, memikirkan rencana, melaksanakan rencana, dan melihat kembali. Sedangkan siswa impulsif dalam menyelesaikan masalah telah dapat memenuhi indikator memikirkan rencana dan melaksanakan rencana. Siswa impulsif cenderung melewatkan tahapan memahami masalah dan melihat kembali.
\end{abstract}

Kata Kunci: Gaya Kognitif, Pemecahan Masalah, Pola Bilangan, Reflektif-Impulsif 


\section{PENDAHULUAN}

Matematika sebagai salah satu mata pelajaran wajib bagi siswa pada jenjang pendidikan dasar, menengah pertama dan menengah atas, bahkan sampai di bangku perkuliahan. Menurut NCTM (2000), siswa harus memiliki lima kemampuan utama matematika yaitu kemampuan pemecahan masalah, penalaran, komunikasi, penelusuran pola atau hubungan, dan representasi. Matematika sangat erat kaitannya dengan pemecahan masalah (problem solving). Menurut Zevenbergen sebagaimana yang dikutip oleh Ulya (2015) dalam memecahkan masalah perlu memiliki pemahaman dan pengetahuan yang memadai, serta memiliki berbagai macam strategi yang dapat dipilih ketika menghadapi masalah yang berbeda. Berdasarkan hasil observasi di kelas VII MTsN 1 Mataram dapat diketahui bahwa sebagian siswa masih mengalami masalah pada saat menyelesaikan soal matematika. Hal ini dapat dilihat dari Tabel 1 yaitu hasil Penilaian Tengah Semester (PTS) siswa kelas VII MTsN 1 Mataram yang pada tahun ajaran 2019/2020 akan menjadi siswa kelas VIII.

Tabel 1. Rata-rata hasil Penilaian Tengah Semester (PTS) MTsN 1 Mataram

\begin{tabular}{ccc}
\hline No. & Kelas & Nilai rata-rata \\
\hline 1 & VII-1 & 85,00 \\
2 & VII-2 & 84,37 \\
3 & VII-3 & 85,00 \\
4 & VII-4 & 62,92 \\
5 & VII-5 & 65,00 \\
6 & VII-6 & 62,67 \\
7 & VII-7 & 81,00 \\
8 & VII- 8 & 81,44 \\
\hline
\end{tabular}

Tabel 1 di atas menunjukkan bahwa nilai rata-rata Penilaian Tengah Semester (PTS) siswa kelas VII-4, VII-5, dan VII-6 masih di bawah Kriteria Ketuntasan Minimal (KKM). Penyebab rendah nilai siswa adalah tingkat keaktifan siswa yang masih kurang, hanya beberapa siswa yang mampu dan mau mengemukakan ide ataupun bertanya kepada guru tentang apa yang belum dimengerti serta kurangnya pemberian soal-soal pemecahan masalah. Ketika diberikan contoh, siswa mengatakan paham, namun ketika diberikan latihan atau pada saat ulangan diberikan soal yang sedikit mengecoh maka siswa mulai kesulitan dan tidak bisa menyelesaikan permasalahan tersebut. Itu artinya siswa hanya menghafal contoh dan belum benar-benar memahami materi pelajaran. Hal ini sesuai dengan pendapat Syaiful, dkk (2011) yang mengatakan bahwa kebiasaan belajar siswa yang dilakukan dengan cara menghafal ini tidak dapat melatih kemampuan pemecahan masalah matematis siswa. Menurut hasil uji coba tes, siswa juga tidak melakukan tahapan pemecahan masalah dengan tepat.

Guru harus menyadari karakter siswa yang berbeda untuk setiap individu. Perbedaan karakter siswa berpengaruh terhadap cara mereka menerima dan memproses pembelajaran. Dalam menyelesaikan masalah, cara yang digunakan setiap siswa pasti berbeda-beda sehingga akan mempengaruhi kecepatan dalam menyelesaikan masalah. Ada siswa yang mampu menyelesaikan masalah dengan waktu yang sangat singkat, namun ada juga siswa yang menyelesaikan masalah dengan waktu yang relatif lama. 
Hal tersebut merujuk pada gaya kognitif siswa. Gaya kognitif berpengaruh terhadap pemecahan masalah siswa. Menurut Nasution (2009) pemecahan masalah dapat dipandang sebagai manipulasi informasi secara sistematis, langkah demi langkah, dengan memperoleh informasi yang diperoleh melalui pengamatan untuk mencapai suatu hasil pemikiran sebagai respons terhadap problema yang dihadapi.

Sesuai dengan pendapat Susan dan Collinson (2005) (dalam Hayuningrat \& Listiawan, 2018) bahwa "general problem solving strategie such as these are further influenced by cognitive style". Yang artinya pada umumnya strategi atau cara pemecahan masalah lebih dipengaruhi oleh gaya kognitif siswa. Gaya reflektif cenderung menggunakan lebih banyak waktu untuk merespon dan merenungkan akurasi jawaban. Individu reflektif sangat lamban dan berhati-hati dalam memberikan respons, tetapi cenderung memberi jawaban secara benar. Hashim berpendapat bahwa pelajar reflektif lambat menyiapkan sesuatu tugas yang diberi tetapi membuat sedikit kesalahan (Hashim et al., 2003). Sedangkan Faizah (2017)mengatakan bahwa siswa dengan gaya reflektif memiliki kecenderungan untuk dapat menentukan tujuan belajar, memiliki standar prestasi, dan pola belajarnya lebih efektif daripada siswa dengan gaya impulsif. Namun kelemahan siswa reflektif selalu merenungkan masalah dan mengalami kesulitan dalam menyelesaikan tugas.

Siswa impulsif ialah siswa yang mempunyai karakteristik cepat dalam menyelesaikan soal, tetapi kurang cermat sehingga jawaban cenderung salah. Pelajar impulsif dapat bekerja dengan cepat tetapi membuat banyak kesalahan (Hashim et al., 2003). Impulsif dapat didefinisikan dengan kecepatan memahami konsep yang melibatkan kecenderungan siswa untuk bertindak cepat, sedangkan gaya reflektif siswa mengambil lebih banyak waktu untuk merespon dan memikirkan sebuah konsep dalam menentukan ketepatan jawaban (Faizah et al., 2017).

Oleh karena itu, perbedaan gaya kognitif akan berpengaruh terhadap kemampuan pemecahan masalah matematika siswa, maka perlu dilakukan penelitian mengenai gambaran kemampuan pemecahan masalah matematika siswa jika dilihat dari gaya kognitif reflektif dan gaya kognitif impulsif. Berdasarkan uraian di atas maka peneliti tertarik melakukan penelitian mengenai Analisis Kemampuan Pemecahan Masalah Matematika pada Materi Pola Bilangan Ditinjau dari Gaya Kognitif Reflektif-Impulsif pada Siswa Kelas VIII MTsN 1 Mataram Tahun Ajaran 2019/2020. Penelitian ini memiliki tujuan untuk mengetahui tingkat kemampuan pemecahan masalah matematika siswa yang bergaya kognitif reflektif dan impulsif dalam menyelesaikan soal pola bilangan kemudian mendeskripsikan tahapan pemecahan masalah dalam menyelesaikan soal pola bilangan.

\section{METODE PENELITIAN}

Jenis penelitian ini adalah penelitian deskriptif. Subjek penelitian ini sebanyak 22 siswa kelas VIII-6 MTsN 1 Mataram yang terdiri dari 14 siswa yang bergaya kognitif reflektif dan 8 siswa yang bergaya kognitif impulsif. Teknik pengumpulan data berupa tes 
Matching Familiar Figure Test yang dikembangkan oleh Warli (2010) untuk mengetahui gaya kognitif siswa. Soal tes MFFT (Matching Familiar Figure Test) terdiri dari 13 gambar ditambah dengan 2 gambar sebagai percobaan. Pada setiap item soal terdapat 1 gambar standar dan 8 gambar variasi dimana hanya ada satu gambar yang benar-benar sama dengan gambar standart. Sedangkan data kemampuan pemecahan masalah matematika siswa menggunakan tes pada materi pola bilangan yang dianalisis dengan menggunakan tahapan pemecahan masalah Polya.

\section{HASIL DAN PEMBAHASAN}

Penelitian ini diawali dengan pengukuran gaya kognitif siswa. Penentuan gaya kognitif dihitung berdasarkan waktu $(t)$ dan frekuensi jawaban siswa yang salah $(f)$. Catatan waktu dan frekuensi menjawab digunakan sebagai batas penentuan siswa yang mempunyai karakteristik reflektif atau impulsif. Selanjutnya dari data waktu $(t)$ dan banyaknya jawaban salah $(f)$, maka ditarik garis yang sejajar dengan sumbu $t$ dan sumbu $f$, sehingga akan membentuk 4 kelompok siswa.

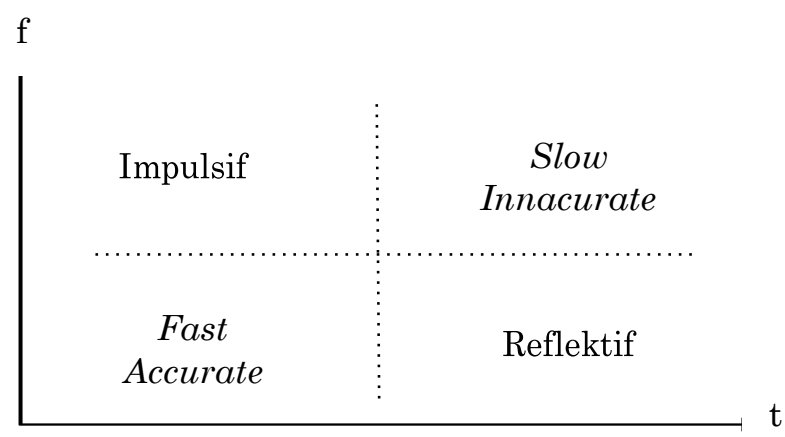

Gambar 1. Sebaran Hasil Tes Gaya Kognitif Siswa Kelas VIII-6 MTsN 1 Mataram

Gambar 1 menunjukkan bahwa sebanyak 40 siswa kelas VIII MTsN 1 Mataram yang mengikuti tes gaya kognitif (Tes MFFT) terbagi menjadi 4 bagian, yaitu 14 siswa tergolong dalam gaya kognitif reflektif, 8 siswa tergolong dalam gaya kognitif impulsif, 4 siswa tergolong dalam gaya kognitif fast accurate dan 14 siswa tergolong pada gaya kognitif slow inaccurate. Dalam penelitian ini hanya akan diulas lebih lanjut mengenai siswa reflektif dan impulsif. Jumlah siswa yang tergolong ke dalam gaya kognitif reflektif sebanyak 14 orang dan siswa yang tergolong ke dalam gaya kognitif impulsif sebanyak 8 orang.

Setelah menggolongkan siswa ke dalam gaya kognitif reflektif dan gaya kognitif impulsif, kemudian dilakukan analisis tentang kemampuan pemecahan masalah siswa pada materi pola bilangan. Dari hasil tes pola bilangan tersebut, diperoleh siswa reflektif memiliki tingkat kemampuan pemecahan masalah dengan kategori tinggi, sedang, dan rendah. Sedangkan siswa impulsif memiliki tingkat kemampuan pemecahan masalah dengan kategori sedang dan rendah. 
Tabel 2. Kualifikasi Gaya Kognitif Siswa dan Tingkat Kemampuan Pemecahan Masalah Matematika Siswa pada Materi Pola Bilangan

\begin{tabular}{cccccc}
\hline $\begin{array}{c}\text { Gaya Kognitif } \\
\text { Siswa }\end{array}$ & $\begin{array}{c}\text { Banyak } \\
\text { Siswa }\end{array}$ & $\begin{array}{c}\text { Nilai } \\
\text { Rata-rata }\end{array}$ & $\begin{array}{c}\text { Tingkat Kemampuan } \\
\text { Pemecahan Masalah Siswa }\end{array}$ & $\begin{array}{c}\text { Banyak } \\
\text { Siswa }\end{array}$ & Persentase \\
\hline Reflektif & \multirow{2}{*}{6} & 67,07 & Tinggi & 5 & $35,7 \%$ \\
& & & Sedang & 7 & $50 \%$ \\
& & & Rendah & 2 & $14,2 \%$ \\
\hline Impulsif & \multirow{2}{*}{8} & \multirow{2}{*}{46,48} & Sedang & 5 & $62,5 \%$ \\
& & & Rendah & 3 & $37,5 \%$ \\
\hline
\end{tabular}

Berdasarkan analisis data dan hasil penelitian diperoleh bahwa nilai rata-rata siswa reflektif yaitu 67,07 termasuk kategori tinggi, sedangkan nilai rata-rata siswa impulsif yaitu 46,48 termasuk kategori sedang. Hal ini menunjukkan bahwa kemampuan pemecahan masalah matematika siswa reflektif lebih baik dibandingkan dengan siswa impulsif. Tabel 2 juga menunjukkan bahwa siswa berkemampuan tinggi dimiliki oleh siswa reflektif sebanyak 5 orang, sedangkan siswa impulsif sebanyak 0 yang berarti tidak ada. Kemudian berdasarkan pedoman penyekoran menurut Polya dan kriteria tingkat kemampuan pemecahan masalah diperoleh kualifikasi kemampuan siswa untuk setiap tahapan pemecahan masalah menurut Polya. Adapun persentase tingkat kemampuan pemecahan masalah matematika siswa pada setiap tahapan pemecahan masalah menurut Polya disajikan sebagai berikut.

Tabel 3. Persentase Tingkat Kemampuan Pemecahan Masalah Matematika Siswa pada Materi Pola Bilangan untuk Setiap Tahapan Pemecahan Masalah

\begin{tabular}{|c|c|c|c|c|c|}
\hline \multirow{3}{*}{ No. } & \multirow{3}{*}{$\begin{array}{c}\text { Tahap-tahap } \\
\text { Pemecahan Masalah }\end{array}$} & \multicolumn{4}{|c|}{ Kualifikasi Kemampuan Siswa } \\
\hline & & \multicolumn{2}{|c|}{ Reflektif } & \multicolumn{2}{|c|}{ Impulsif } \\
\hline & & $\begin{array}{l}\text { Banyaknya } \\
\text { Siswa }\end{array}$ & $\begin{array}{l}\text { Persentase } \\
\text { Siswa }\end{array}$ & $\begin{array}{l}\text { Banyaknya } \\
\text { Siswa }\end{array}$ & $\begin{array}{l}\text { Persentase } \\
\text { Siswa }\end{array}$ \\
\hline 1 & Memahami Masalah & 11 & $78.5 \%$ & 3 & $37.5 \%$ \\
\hline 2 & Memikirkan Rencana & 8 & $57.1 \%$ & 5 & $62.5 \%$ \\
\hline 3 & Melaksanakan Rencana & 6 & $42.8 \%$ & 3 & $37.5 \%$ \\
\hline 4 & Memeriksa Kembali & 5 & $35.7 \%$ & 1 & $12.5 \%$ \\
\hline
\end{tabular}

\subsection{Perbandingan Subjek Reflektif dan Impulsif dalam Tahap Memahami Masalah}

Pada tahap memahami masalah, siswa reflektif dalam menyelesaikan soal dapat memenuhi indikator memahami masalah yaitu menuliskan apa yang diketahui dari soal, menuliskan apa yang ditanyakan pada soal, dan menjelaskan kembali soal dengan menggunakan bahasa sendiri. Hal ini sesuai dengan penelitian Puspita dan Wijayanti (2016) bahwa siswa bergaya kognitif reflektif menceritakan kembali maksud dari soal dengan benar dan menggunakan kata-katanya sendiri secara lengkap dan terurut.

Sedangkan siswa impulsif dalam menyelesaikan soal dapat memenuhi indikator memahami masalah yang meliputi menuliskan apa yang diketahui dari soal tetapi tidak lengkap bahkan ada yang keliru dan tidak menuliskannya sama sekali, menuliskan apa yang ditanyakan pada soal, dan ketika diminta menjelaskan kembali soal dengan bahasa sendiri, siswa impulsif menjelaskan kembali soal dengan menggunakan bahasa soal atau hanya mengulang membaca soal. Hal ini sesuai dengan penelitian Puspita dan Wijayanti 
(2016) bahwa siswa bergaya kognitif impulsif menceritakan kembali maksud dari soal dengan benar dan menggunakan bahasa yang sama dengan soal untuk kedua soal yang diberikan.

\subsection{Perbandingan Subjek Reflektif dan Impulsif dalam Tahap Memikirkan Rencana}

Pada tahap memikirkan rencana, siswa reflektif dalam menyelesaikan soal dapat memenuhi indikator dari menyusun rencana yaitu mencari hubungan antara hal-hal yang diketahui, hal-hal yang belum diketahui, dengan hal-hal yang ditanyakan. Siswa reflektif juga dapat menentukan rumus yang digunakan untuk menyelesaikan soal. Siswa reflektif dapat menuliskan secara rinci apa yang harus ditemukan terlebih dahulu untuk disubstitusikan ke dalam rumus. Sesuai dengan penelitian Nasriadi (2017) yang mengatakan bahwa sebelum melakukan pemecahan masalah, subjek menentukan konsep atau operasi yang yang akan digunakan terlebih dahulu. Sedangkan siswa impulsif dalam menyelesaikan soal dapat memenuhi indikator dari menyusun rencana yaitu mencari hubungan antara hal-hal yang diketahui, hal-hal yang belum diketahui, dengan hal-hal yang ditanyakan tetapi tidak menuliskannya pada lembar jawaban, ia langsung menuliskannya saat disubstitusikan ke dalam rumus. Siswa impulsif juga dapat menuliskan rumus yang digunakan untuk menyelesaikan soal tetapi masih ada kekeliruan saat menuliskan rumus, bahkan ada yang tidak menuliskan rumus dan langsung ke perhitungan.

\subsection{Perbandingan Subjek Reflektif dan Impulsif dalam Tahap Melaksanakan Rencana}

Pada tahap melaksanakan rencana, siswa reflektif dalam menyelesaikan soal dapat memenuhi indikator dari melaksanakan rencana yaitu, mampu menyelesaikan soal sesuai rencana. Hal ini sesuai dengan pendapat Nasriadi (2017) subjek yang bergaya kognitif reflektif melaksanakan rencana sesuai dengan strategi yang dijelaskan pada tahap rencana pemecahan masalah. Indikator selanjutnya yang dipenuhi oleh siswa reflektif yaitu mampu menerapkan setiap rumus yang telah ditentukan untuk menyelesaikan masalah, serta menggunakan keterampilan algoritma dan perhitungan dalam menyelesaikan masalah. Sedangkan siswa impulsif dalam menyelesaikan soal tidak dapat memenuhi indikator dari melaksanakan rencana yaitu menyelesaikan soal sesuai dengan rencana karena tidak tahu rumus yang akan digunakan meskipun dapat melakukan perhitungan dengan tepat. Siswa impulsif mencoba rumus asal-asalan untuk menemukan pola dari soal.

\subsection{Perbandingan Tahapan Melihat Kembali antara Subjek Reflektif dan Impulsif}

Pada tahap melihat kembali, siswa reflektif dalam menyelesaikan soal dapat memenuhi indikator dari melihat kembali yaitu menuliskan kesimpulan dari jawaban seperti mencocokan hasil yang diperoleh dengan hal yang ditanya dan memeriksa kembali jawaban yang diperoleh dengan mengidentifikasi adakah cara lain untuk mendapatkan penyelesaian masalah. Sedangkan siswa impulsif dalam menyelesaikan soal dapat 
memenuhi indikator dari melihat kembali yaitu menuliskan kesimpulan dari jawaban seperti mencocokan hasil yang diperoleh dengan hal yang ditanya tetapi tidak memeriksa kembali kebenaran jawaban yang diperoleh karena tidak tahu cara mengecek kebenaran jawaban yang diperoleh.

\subsection{Perbedaan Kemampuan Pemecahan Masalah Subjek Reflektif dan Impulsif}

Setelah meninjau tahapan pemecahan masalah dari siswa yang bergaya kognitif reflektif dan impulsif dalam menyelesaikan soal dapat dilihat dari indikator yang dipenuhi oleh masing-masing gaya kognitif dari mulai tahap memahami masalah, memikirkan rencana, melaksanakan rencana, dan melihat kembali dapat dikatakan siswa reflektif lebih unggul dibandingkan dengan siswa impulsif. Hal ini disebabkan karena siswa yang bergaya kognitif reflektif cenderung menggunakan lebih banyak waktu dan lebih teliti dalam menyelesaikan masalah. Ketelitian dan kecermatan siswa reflektif dalam menyelesaikan masalahnya, sesuai dengan pendapat Kagan dalam Stannard [10] yang mengatakan bahwa siswa reflektif sangat berhati-hati dan memanfaatkan semua alternatif. Kemudian waktu yang digunakan relatif lama dalam merespon tetapi kesalahan yang dibuat relatif kecil.

Sedangkan siswa impulsif menggunakan waktu yang relatif cepat dalam merespon, tetapi cenderung membuat kesalahan karena mereka tidak memanfaatkan semua alternatif. Hal ini sesuai dengan pendapat Kagan (Lucas-Stannard, 2004) yang mengemukakan bahwa orang yang memiliki gaya kognitif impulsif menggunakan alternatif-alternatif secara singkat dan cepat untuk menyeleksi sesuatu. Pada siswa impulsif sering melewatkan tahapan memahami masalah yaitu tidak menuliskan apa yang diketahui dan tahapan melihat kembali yaitu menuliskan kesimpulan dan memeriksa kebenaran jawaban yang diperoleh. Berdasarkan uraian tersebut, didapatkan perbedaan siswa reflektif dan siswa impulsif adalah sebagai berikut.

Tabel 4. Perbedaan Siswa Reflektif dan Impulsif

\begin{tabular}{|c|c|c|}
\hline No & Siswa Reflektif & Siswa Impulsif \\
\hline 1 & $\begin{array}{l}\text { Mampu menuliskan apa yang } \\
\text { diketahui dan ditanyakan } \\
\text { dengan benar dan lengkap. }\end{array}$ & $\begin{array}{l}\text { Mampu menuliskan apa yang } \\
\text { diketahui dan ditanya dari soal dengan } \\
\text { kurang lengkap dan } \\
\text { bahkan tidak menuliskannya. }\end{array}$ \\
\hline 2 & $\begin{array}{l}\text { Mampu menjelaskan soal dengan } \\
\text { bahasa sendiri. }\end{array}$ & $\begin{array}{l}\text { Mampu menjelaskan soal dengan } \\
\text { bahasa soal atau dengan membaca } \\
\text { ulang soal. }\end{array}$ \\
\hline 3 & $\begin{array}{l}\text { alam melakukan } \\
\text { ngan dalam menyelesaikan } \\
\text {. }\end{array}$ & $\begin{array}{l}\text { Kurang teliti dalam melakukan } \\
\text { perhitungan dalam menyelesaikan } \\
\text { masalah. }\end{array}$ \\
\hline 4 & $\begin{array}{l}\text { Mampu mengaitkan antara hal-hal } \\
\text { yang diketahui, hal-hal yang belum } \\
\text { diketahui dan apa yang ditanyakan } \\
\text { pada soal dan menuliskannya. }\end{array}$ & $\begin{array}{l}\text { Mampu mengaitkan antara hal-hal } \\
\text { yang diketahui, hal-hal yang belum } \\
\text { diketahui dan apa yang ditanyakan } \\
\text { pada soal tetapi tidak menuliskannya. }\end{array}$ \\
\hline & $\begin{array}{l}\text { Melakukan pengecekan kembali } \\
\text { terhadap jawaban yang diperoleh. }\end{array}$ & $\begin{array}{l}\text { Tidak melakukan pengecekan kembali } \\
\text { terhadap jawaban yang diperoleh. }\end{array}$ \\
\hline
\end{tabular}




\section{SIMPULAN}

Berdasarkan hasil penelitian dan pembahasan yang telah dipaparkan maka dapat diambil kesimpulan bahwa:

a. Tingkat kemampuan pemecahan masalah matematika siswa reflektif adalah tinggi, sedang, dan rendah dengan persentase secara berturut-turut sebesar 35,7\%, 50\%, dan $14,2 \%$.

b. Tingkat kemampuan pemecahan masalah matematika siswa impulsif adalah sedang dan rendah dengan persentase secara berturut-turut sebesar $62,5 \%$ dan $37,5 \%$.

c. Siswa reflektif membutuhkan waktu yang relatif lama dan jawabannya cenderung lengkap dan benar. Siswa reflektif yang berkemampuan tinggi dan sedang telah dapat memenuhi indikator pada tahapan Polya yaitu memahami masalah, memikirkan rencana, melaksanakan rencana, dan melihat kembali. Sedangkan siswa reflektif yang berkemampuan rendah melewatkan tahapan melihat kembali.

d. Siswa impulsif membutuhkan waktu yang cepat dan jawabannya cenderung tidak lengkap dan salah. Siswa impulsif yang berkemampuan sedang dapat memenuhi indikator pada tahapan Polya yaitu melihat kembali, memikirkan rencana dan melaksanakan rencana, namun enggan memeriksa kembali jawaban yang diperoleh. Sedangkan siswa impulsif yang berkemampuan rendah dapat memenuhi indikator memahami masalah, memikirkan rencana, dan melaksanakan rencana namun pada tahap memahami masalah siswa impulsif yang berkemmpuan rendah menulis ulang sesuai soal bahkan ada yang melewatkan tahapan memahami masalah. Siswa impulsif yang berkemampuan rendah juga melewatkan tahapan melihat kembali.

\section{REFERENSI}

Faizah, Rahma, U., \& Dara, Y. P. (2017). Psikologi Pendidikan: Aplikasi Teori di Indonesia. Malang: TIM UB Press.

Hashim, S., Razali, M., \& Jantan, R. (2003). Psikologi Pendidikan. Selangor: PTS Publications \& Distributors Sdn. Bhd.

Hayuningrat, S., \& Listiawan, T. (2018). Proses Berpikir Siswa dengan Gaya Kognitif Reflektif dalam Memecahkan Masalah Matematika Generalisasi Pola. Jurnal Elemen, 4(2), 183-196. https://doi.org/10.29408/jel.v4i2.752

Lucas-Stannard, P. (2004). Cognitive Styles : A Review of the Major Theories and Their Application to Information Seeking in Virtual Environments. Journal of the American Society for Information Science, 40(1), 54-66.

Nasriadi, A. (2017). Profil Pemecahan Masalah Matematika Siswa SMP Ditinjau dari Gaya Kognitif Reflektif dan Impulsif. STKIP Bina Bangsa Getsempena.

Nasution, M. A. (2009). Kurikulum dan Pengajaran. Jakarta: Bumi Aksara.

NCTM. (2000). Principles and Standards for School Mathematics. In The National Council of Teachers of Mathematics, Inc. The National Council of Teachers of Mathematics, Inc. https://www.cambridge.org/core/product/identifier/S0007125000082039/type/journal_article

Puspita, A. Y. A., \& Wijayanti, P. (2016). Profil Pemecahan Masalah Matematika Siswa pada Materi Segiempat Ditinjau dari Gaya Kognitif Reflektif dan Impulsif. Jurnal MATHEdunesa, $5(3), 17-27$.

Syaiful, Kusumah, Y. S., Sabandar, J., \& Darhim. (2011). Peningkatan Kemampuan Pemecahan 
Indah dkk Analisis kemampuan pemecahan masalah ...

Masalah Matematis Melalui Pendekatan Matematika Realistik. Jurnal Pendidikan Matematika Dan Sains, 1(XVI), 9-16.

Ulya, H. (2015). Hubungan Gaya Kognitif dengan Kemampuan Pemecahan Masalah Matematika Siswa. Jurnal Konseling GUSJIGANG, 1(2). 